\title{
LAND ACCESS ISSUES IN FOSSIL COLLECTING
}

BARNA, Frank C., Bureau of Land Management (WO340), Washington, DC 20240, U.S.A.

The 270 million acres of Public Lands administered today by the Bureau of Land Management (BLM) constitute America's largest outdoor paleontological laboratory and classroom. It has nearly always been so. Fossils excited the curiosity of Native Americans, some of whom considered fossil bones to be the remains of giants. Later, American explorers, such as Lewis and Clark, noted the occurrence of fossils in their journals. By the 1870's, the Public Lands became the setting for a veritable "dinosaur gold rush." Contemporary giants of science, researchers such as O.C. Marsh and E.D. Cope, sought out the remains of the one-time giants of the earth, Apatosaurus, Camarasaurus, Diplodocus and Allosaurus, in remote places like Garden Park, Colorado, and Como Bluff, Wyoming.

Today, these lands continue to support the public's keen interest in paleontology. Working within the mandates of the Federal Land Policy and Management Act (FLPMA), which requires that the Public Lands be managed in a manner that protects their scientific, historical, scenic, environmental and other values, the BLM seeks to facilitate the appropriate scientific, educational and recreational uses of paleontological resources. Hobby and amateur collectors have general access to Public Lands for the collection of reasonable amounts of common invertebrate fossils and limited amounts of petrified wood. Such collections may be made without a permit, but must be for personal, noncommercial purposes. In order to help us protect other sensitive resources, and to determine that local conditions, such as roads, are accessible and safe, visitors to the Public Lands are encouraged to contact the nearest BLM office for specific area information.

Due to the relative rarity and scientific importance of fossil vertebrates, the Department of the Interior has, historically, required a permit for their collection. Notwithstanding this permit requirement, the BLM supports the desire of professional vertebrate paleontologists to involve the amateur community in scientific research. BLM has successfully worked with educational institutions to host paleontological training courses so that serious amateurs can make more meaningful contributions to science and also help land managers become more knowledgeable stewards of the resources under their care. 